\title{
RENDERING FUNCTION FEATURES OF THE FRENCH COLLOQUIAL INTERROGATIVE CONSTRUCTIONS IN UKRAINIAN FICTION TRANSLATION
}

\author{
Andriy Bilas \\ Higher State Educational Establishment of Ukraine "Vasyl Stefanyk Precarpathian National \\ University”, Ivano-Frankivsk, Ukraine \\ bilas_andriy@ukr.net
}

\begin{abstract}
The article deals with the problems of colloquial interrogative sentences having the function features in the source and target fiction texts. The importance of the research of interrogative sentences is defined by frequent use of questioning in the process of communication and a close connection of the problem of questioning with other sociolinguistic issues. The given paper outlines function features of the colloquial interrogative sentences on the material of J.-M. Guenassia's "The Incorrigible Optimists Club" and its Ukrainian translation by means of the analysis of possible ways of their rendering into Ukrainian. The author takes into account many works devoted to the study of questioning as a linguistic and translation category, paying special attention to the place of interrogative sentences in the French colloquial speech. The analysis of the colloquial interrogatives functioning in J.-M. Guenassia's novel "The Incorrigible Optimists Club" allows the author to conclude that translation difficulties are caused not so much by their text-functional features, but rather by their structural, semantic, figurative, and socio-functional characteristics, as well as by the asymmetry of the structural elements and register polyphony of the source and target languages.
\end{abstract}

Keywords: translation; rendering; colloquial interrogative sentences; functional features; transformations; Wh-question; adequacy of translation.

\section{Introduction}

The interrogative expression is one of the important problems of modern linguistics and translation studies. The analysis of such types of sentences remains the topical issue nowadays since the nature of interrogative sentences is being interpreted ambiguously, mostly considering only some of their functional aspects. At the present stage of the development of the translation and linguistic sciences, little attention is paid to this kind of sentences.

Although the importance of this topic is evident, the sociolinguistic and communicative aspects of the interrogative sentences pragmatics are still poorly studied within the sphere of translation. Since the communicative-pragmatic equivalence is one of the most important requirements of the fiction translation, it is worth paying special attention to the social-functional component of the interrogative sentence pragmatic orientation to be rendered as the adequate communicative effect in its translation. The adequate translation is not possible without preserving the colloquial-register charge of the original interrogatives in the translation process.

In view of the fact that the interrogative sentences have repeatedly been the subject of linguistic analysis, their socio-functional aspect did not receive sufficient elucidation in the field of translation. Their structural-semantic and functional updating in the translation process has not been studied sufficiently, which also determined the relevance of the subject matter of this paper.

In modern linguistics and translation studies, the category of questioning is often considered within the framework of functional syntax, communication theory and pragmatics, by overlooking the socio-functional component of the linguistic content of the interrogatives, or even the problem of rendering their socially marked functions, caused by language changes in the translated text. For Waltereit (2018) language change, in essence, is a socially motivated shift in usage patterns of variants. In other words, language change is spread through the speech community. Under the variationist approach, variation is always there, so that there is not that much focus on individual innovations. In fact, innovations are seen as a necessary byproduct of ordinary speech (Waltereit, 2018, p. 57).

The variety of interpretations of the interrogative expression category is explained by the difference in the criteria that underlie its interpretation. Many scientific studies express the idea of the need to delimit the interrogative sentence as a syntactic category from the semantic understanding of the question as a statement with the function of the information request (Almanova, 2011, p. 100).

Suzov (2009) draws attention to the question interpretation, mentioned in their works as "interrogative", as a motivating, non-institutional (non-ritual), and initially addressed, informational and motivational kind of the speech act (p. 131). The interrogative, like any other speech act, has a three-component structure (locutionary, illocutionary and perlocutionary acts), the act of perlocution acquiring a special meaning since the question is to get an answer, that is, it is directed at the reaction (Almanova, 2011, p. 100-101).

Bilas, A. (2019). Rendering function features of the French colloquial interrogative constructions in Ukrainian fiction translation. Advanced Education, 12, 188-195. DOI: 10.20535/2410-8286.139167 
It is well-known that to get information is very important for human species. Apparently, as Siemund (2001) believes, most languages have developed some particular means dedicated to eliciting information, henceforth called interrogative constructions or simply interrogatives. In addition, there is always the option to eschew interrogatives and use non-canonical means for obtaining information (Siemund, 2001, p. 1010).

Although the existence of interrogative constructions seems to be a universal property of natural languages, languages differ substantially in the strategies they employ for coding interrogatives, what is so important in their translating. Siemund (2001) offers to distinguish seven basic means of interrogatives, some of them being restricted to particular types of interrogatives: intonation, interrogative particles, interrogative tags, disjunctive constructions, the order of the constituents, verbal inflection and interrogative words. Some of these strategies can occur in combination, others may be mutually exclusive (Siemund, 2001, p. 1011).

For translation studies, the investigation of various types of linguistic units rendering, including colloquial interrogatives, from the point of view of preserving the social and communicative content realised in the communication process, in particular, of the characters of modern fiction discourse, is very relevant. The objectives of our scientific research are to clarify the problem of the adequate rendering of the interrogative sentences with modern French colloquial socio-communicative content, which is realised on the basis of a broad context. We mean "a broad context" as "not only a distinct environment of words, phrases or statements, but also as a broad semantic context, which does not have virtually any formal and material limits, if we see that this context includes unlimited vital and therefore verbal experience of communicants" (Sitko \& Zhuravlova, 2007, p. 155).

In this case, the special role of interrogative in the deployment of the communication process is notable: the question is an element that prompts the interlocutor to give information, stimulates the deployment of the context, activates the speech action in the dialogue and expresses the communicator's relation to the subject of the request and the interlocutor (Sitko \& Zhuravlova, 2007, p. 155). Consequently, the focus should not be only on the structural features of the colloquial question elements, but also on their socio-communicative functions. Investigating wh-movement and subject-verb-inversion (stylistic inversion) in wh-constructions in European French, Adli (2013) proposes an analysis of the subjective side of social structure, which reveals salient patterns of sociolinguistic variation that would otherwise remain undetected and shows that lifestyle is a very prominent element of the variable set (p. 473).

Lefeuvre and Rossi-Gensane (2017) defend the hypothesis that non-standard interrogative clauses are close to independent clauses. They also prove that total and partial non-standard indirect interrogative clauses are, to a very great extent, outnumbered by their standard counterparts in informal spoken French (p. 51-74).

In French main clause, interrogatives depend partly on the register. One of the three variants is present in colloquial French, which is considered as a different grammar. In this latter case, the mono-clausal question used without inversion and interrogativity is indicated only by rising intonation at the end of the sentence. (Gazdik, 2007, p. 275). In informal French, the wh-word is always in situ. The input is similar to that of the simplex candidate in formal French, but due to the different constraint hierarchy, another candidate is selected as the optimal one: Vous cherchez qui? [Who you are looking for?] (Gazdik, 2007, p. 286).

The interrogatives in situ, as M. Barra-Jover asserts, are not interpretable as requests for information, although this statement deserves to be qualified. The SVQ interrogatives (i.e. - Et tu as acheté quoi? [And what did you buy?]) can express the same requests for information as interrogatives with $\mathrm{Q}$ at the top of the sentence (Barra-Jover, 2004, p. 112).

So, the research is aimed at studying the ways of rendering the function peculiarities of colloquial interrogative sentences in the source and target French fiction text. It can be considered as an attempt of the social and communicative analysis of the French colloquial interrogative structures in the translation area, expressing not only the value of the interrogative meaning, but also "expanding the meanings of other types of modal-intentional statements - constatives, expressives, imperatives" (Sitko \& Zhuravlova, 2007, p. 155).

\section{Method}

The study of rendering the interrogative sociolinguistic and socio-communicative content is possible by using the translation and communicative-pragmatic methods of analysis. The socio-communicative analysis of French colloquial interrogative statements should primarily focus on the study of specific meanings that can be transmitted in a question form, as well as the identification of the colloquial interrogative role in specific speech acts - their socially marked functions or variations in a variety of speech tactics.

The specificity of the topic caused an integrated approach to the use of research methods, including: descriptive - for selecting, ordering and interpreting factual material; comparative - for the analysis and 
synthesis of scientific theories; methods of linguistic observation and systematisation - to separate colloquial interrogatives into groups on the basis of differential characteristics.

The methods of stylistic and semantic analyses helped establish the semantic content and stylistic aspects of colloquial means in a fiction text. Using the method of functional and stylistic analysis of the colloquial language of modern French prose texts describes the stylistic rate of colloquial interrogative sentences functioning in the works of writers. The qualitative data analysis is to analyse the colloquial interrogative sentences function features in the source and target texts.

\section{Results and discussion}

In the following paragraphs, we will focus on rendering the function features of the French colloquial interrogative constructions in J.-M. Guenassia's novel "The Incorrigible Optimists Club" (Guenassia, 2009). In the history of linguistic studies, the research of the interrogative sentences was conducted in line with their particular aspect. So, the question was considered as a correlate of linguistic judgment, a specific orientation of the theme-rheme structure, interrogative transformations of nuclear sentences, sentences of interrogative modality, certain speech acts - quesitives (Andrus, 2007, p. 4).

In linguistics, there are different views on the classification of the interrogative sentences. O. Paziak made a division of the interrogative sentences by the emotional shades, distinguishing the properly interrogative sentences, which are used in dialogues and polylogues; rhetorical questions, that contain a hidden statement and do not require an answer, and imperative question sentences, which contain a call to action (as cited by Ponomariv, 2005, p. 295).

Shabat (2001) classifies interrogative sentences into the communicative and functional orientation: properly interrogative sentences, in which request-search of information is contained, its clarification and refinement; contact interrogative sentences, in which request is a way of maintaining contact with the interlocutor; imperative interrogative sentences, which perform the request-motivation of the action; constatives and rhetorical interrogative sentences, which outline the request-statement of information; optative interrogative sentences, which contain the request-desire; authorised-estimated interrogative sentences that contain the request-authorised value (p. 54).

We begin the translation analysis of J.-M. Guenassia's "The Incorrigible Optimists Club" by comparing the contact interrogative sentence in the original and the translation. It discovered the syntactic asymmetry and functional symmetry of the bilingual counterparts. For example, after Michel crossed the threshold, Pierre ran and took to acquaint them using a colloquial form of the interrogative sentence:

- Tu connais ma sæur, p'tit con? [You know my sister, little fool?] (Guenassia, 2009, p. 49);

- Знайомий із моєю сестрою, дурнику? [You know my sister, little fool?] (Guenassia, 2017, p. 55).

Various studies of spoken French indicate that questions of the declarative type, commonly called intonation questions, are largely the most frequent, those with est-ce que are about $10 \%$ and those with particles are very rare, although the elliptical alternatives structures are rarely taken into account (Dagnac, 2013):

- C'est moi... Michel. Tu te souviens? [It's me ... Michel. Do you remember?]

- Michel?... Le petit Michel? [Michel? ... The little Michel?] (Guenassia, 2009, p. 14);

- Це я....Мішель. Пригадуєш? [It's me ... Michel. Do you remember?]

- Мішель? ... Малий Мішелю? [Michel? ... The little Michel?] (Guenassia, 2017, p. 13).

Let's analyse an example of rendering the colloquial properly interrogative in Ukrainian translation in the episode when Franck, as always, began to teach Michel because he had a bad mood - perhaps Pierre's letter threw him off balance: - Tu ferais mieux de bosser les maths que d'écouter du rock. Où elles sont, tes belles résolutions? Envolées. T'as déjà renoncé? [You'd better cram maths than listen to rock. Where they are, your beautiful resolutions? Have flown. You have already given up?] (Guenassia, 2009, p. 66). The translator adequately reproduces emotiveness of the interrogative source sentence that affirms the existence of the symmetry as well as of the asymmetry of the colloquially marked interrogative sentences of the studied languages: - Ти б краще зубрив математику, ніж слухав рок. Куди поділися всі твої добрі наміри? Щезли? Уже капітулював? [You'd better cram maths than listen to the rock. Where have all your good intentions gone? Have disappeared? You have already given up?] (Guenassia, 2017, p. 75).

Pavel's clarifying interrogative remarks (- Où elles sont tes belles résolutions? [Where they are, your beautiful resolutions?] T'as déjà renoncé? [You have already given up?]) get certain modifications in translation. In the first case, the translator subtly felt the contextual semantic loading of the expression ("place") and therefore applies a method of specification in the target text that helps the reader adequately perceive the semantic and stylistic information of the original: - Куди поділися всі твої добрі наміри? [Where have all your good intentions gone?] (Guenassia, 2017, p. 75). In the second case, the translator doesn't preserve the colloquial style of the original expression and slightly increases the expressiveness of 
the sentence, using the method of syntax transformation: - Уже капітулював? [Yои have already given up?] (Guenassia, 2017, p. 75).

This conventionalised relationship between the syntactic structure or clause type and the conversational use is by no means isomorphic and in actual use declaratives and interrogatives may be associated with other speech acts (Siemund, 2001, p. 1011). For instance, we frequently find declaratives used as questions and interrogatives in the function of directives. The translation of the declarative interrogative sentences, addressed to the interlocutor, requires only the proof that the expressiveness in the very question does not always cause difficulties, that is shown in the example of the colloquial source interrogative sentence below, expressed by the direct word order in the target text. In this case, the madam wanted to sit at banquet and asked: - La place est libre? [The place is free?] (Guenassia, 2009, p. 17) - Біля вас вільно? [Nехt tо уои, [it's] free?] (Guenassia, 2017, p. 16). But we can observe some syntax transformation in translation: $L a$ place est libre [The place is free] consists of four elements and Біля вас вільно [Next to you, [it's] free?] has only three.

Just as the non-interrogative clauses can be used to elicit information, it is equally possible to employ interrogatives for the purposes other than asking questions. The use of the interrogatives as directives can be demonstrated in the example:

- Tu m'as entendu? Tout de suite! [Did you hear me? Right now!] (Guenassia, 2009, p. 43);

- Ти не почув? Махом! [You didn't hear me? Right now!] (Guenassia, 2017, p. 48).

The translator often uses syntax transformations rendering colloquial interrogative sentence marked intonationally, as we can see in the episode when Pavel met Michel, hugged him close to him and surprised his friend by his statement:

- Je suis heureux de te revoir. Les autres ne sont pas avec toi? Tu es venu seul? [I'm happy to see you again. The others are not with you? You have come alone?] (Guenassia, 2009, p. 13);

- Радий знову тебе бачити. Решта не з тобою? Ти прийшов сам? [Glad to see you again. The rest are not with you? You have come alone?] (Guenassia, 2017, p. 22).

Colloquial language, full of familiarity, vernacular and argot lexemes, creates difficulties for the translator, also caused by the asymmetry of register filling of the French and Ukrainian languages that cannot leave interrogative sentences with lowering elements untouchable. In the novel under study, we find such sentences only with the colloquial familiar component, which is expressed mostly by neutral means, that causes others stylistic effects and reduces the adequacy of translation. We illustrate this with the affirmative interrogative used by a woman in the case when she was surprised by such rudeness and reacted rather emotionally:

- Non mais je rêve! Tu as vu cette bande de cons qui se déplacent pour ce connard. Ils ont de la merde dans la tête ou quoi? [No, but I dream! You saw this bunch of morons moving for that bastard. They have shit in their heads or what?] (Guenassia, 2009, p. 17);

- Уявити тільки! Поглянь на июю зграю телепнів... Припхалися сюди заради того йолопа. Що за лайно в їхніх головах? [Just imagine! Look at this pack of blockheads... They have come here for this dummy. What's crap in their heads?] (Guenassia, 2017, p. 16).

Negative interrogative sentences only partially perform the communicative function of requesting information, which is transposed to request confirmation of the expressed evaluation (Orlova, 2009, p. 15). The basic emotions that are expressed by means of this type of statements are blame and surprise that we can feel in the question of Igor to Michel: - Tu ne joues pas? [You do not play?] (Guenassia, 2009, p. 435). For the reader's better feeling of the emotive charge of the interrogative, the translator uses the technique of concretisation: - Ти не ставиш? [You don't put?] (Guenassia, 2017, p. 454).

Another colloquial negative interrogative is reealised by its elliptic form (without a subject Vous) and a vernacular marker $Z$ ' of French "fonetic ortograf": - Z'êtes pas au cinéma? [[You] aren't in the cinema?] (Guenassia, 2009, p. 56). A. Shvedyk does not render directly the low register markedness of this sentence, but she emphasises it by an intensifier - the pronoun $\varkappa_{0}$ [what], that slightly increases the expressiveness of the sentence, using the method of syntax transformation: - Ви що, не в кіно? [Yоu, what, [are] not in the cinema?] (Guenassia, 2017, p. 64).

There is another example of non-successful translation of colloquial interrogatives with repeating subject pronoun Tu expliques ça, toi? [You explain that, you?] (Guenassia, 2009, p. 17). The translator did not find this linguostylistic phenomenon equivalent in colloquial Ukrainian that is why she uses semantic and syntax transformations eliminating a low register marker: Можеш ие якось пояснити? [Yои сап ехрlain it somehow?] (Guenassia, 2017, p. 16).

Here is another example of the successful translation of colloquial question though A. Shvedyk uses vernacular настукати [to rat out] instead of the usual standard word denouncer in the meaning of "rat out": 
- Tu vas me frapper? ... Tu vas me dénoncer? [You are going to hit me? ... You are going to denounce me?] (Guenassia, 2009, p. 43);

- I щзо, вдариш мене? ... Настукаєш батькам? [And what, you'll hit me? ... You'll rat out your parents?] (Guenassia, 2017, p. 48).

The language of J.-M. Guenassia's novel is full of contractions of the pronoun $t u\left(t^{\prime}\right)$ [you]. It causes difficulties in translating such a French colloquial phenomenon into Ukrainian for the reason that colloquial Ukrainian has no similar contraction forms. Therefore, the translator is obliged to search for another way to render French contracted pronouns. For example, A. Shvedyk applies the compensation method in another place changing standard Kydu [Where] to vernacular Kyda ["Whera"] and adds the pronoun ue [it] to preserve the colloquial colouring of the original text:

- T'avais disparu? [You had disappeared?] (Guenassia, 2009, p. 59);

- Куда це ти зник? [Where the hell you had disappeared?] (Guenassia, 2017, p. 67).

Sometimes the translator uses partitioning as a translation technique. She breaks the original colloquial interrogative sentence into two sentences:

- Pour la pension, tu ne parlais pas sérieusement? [About the pension, you weren't speaking seriously?] (Guenassia, 2009, p. 56);

- Пансіон? Ти ие серйозно? [The pension? Yои are serious?] (Guenassia, 2017, p. 64).

According to the communicative intentions of the characters, we have discovered the question-blame, question-suggestion, question-invitation, question-request and rhetorical questions. The basis of the classification of interrogatives is their role in the process of direct communication between the two partners of the dialogue (Vynantova, 2011, p. 11). Therefore, the definition of the functional-semantic type of the question is made according to the type of the answer. Here are some examples of the question-blame $(1,2)$ and the question-suggestion (3):

1) - T'es malade? [You're sick?] (Guenassia, 2009, p. 71) - 3дypiв? [Fools?] (Guenassia, 2017, p. 80);

2) - C'est quoi cette bagnole? [What a jalopy is this?] (Guenassia, 2009, p. 85) - Що за корито? [What a trough is this?] (Guenassia, 2017, p. 95);

3) - Qu'est-ce que tu essayes de prouver, que tu es riche? [What you are trying to prove, that you are rich?] (Guenassia, 2009, p.84) - Що ти намагаєшся довести? Що ти багатий? [What yоu are trying to prove? That you are rich?] (Guenassia, 2017, p. 94).

In our studies, we trace a number of transformations, which occur primarily because of the asymmetry of the syntax of the source languages and translation systems (Orlov, 2001, p. 330) which is also characteristic to Ukrainian and French languages. Such asymmetry causes stylistic losses in the process of translation. However, the loss of the colloquial-familiar colouring of the initial interrogative is also happening under the current asymmetry of the two languages, including the removing of the interrogative word to the end of the sentence. Let's compare:

1) - Tu veux dire quoi? Qu'on me fait une blague? [You mean what? That you are making fun of me?] (Guenassia, 2009, p. 586) - Що ти хочеш сказати? Мене розіграли? [What you want to say? You have made fun of me?] (Guenassia, 2017, p. 613).

Ur. Shlonsky traces the lines of a coherent description of wh-in-situ in French and observes five strategies of colloquial wh-interrogation:

1) in-situ: Tu as quitté qui? [you have left who?],

2) wh-movement or overt movement: Qui tu as quitté? [who you left?]

3) wh-cleft: C'est qui que tu as quitté? [It is who that you have left?]

4) wh-movement of cleft pivot: Qui c'est que tu as quitté? [Who it is that you have left?]

5) wh-movement + [est-ce-que]: Qui est-ce que tu as quitté? [Who is-it that you have left?] (Shlonsky, 2012, p. 242).

Now we give an example of the non-successful rendering of wh-in-situ questions because the translator does not keep the original colloquial structure in the target text reducing its adequate comprehension:

- Vous êtes incapable de marcher. Vous allez faire quoi ? [You are unable to walk. You are going to do what?] (Guenassia, 2009, p. 562);

- Ви не здатні ходити. Що ви надумали? [You are not able to walk. What you have thought?] (Guenassia, 2017, p. 587).

The analysis of wh-in-situ in French rests upon a discourse-configurational analysis of interrogatives. In particular, young adults in France apparently consider sentences such as quite natural in everyday conversation. That's why Cheng and Bayer (2017) note that there is vast speaker-variation. French wh-insitu has also been associated with a particular discourse context (pp. 13-32). 
Discussing the wh-phrases, Cheng (2003) looks at wh-in-situ from the licenser perspective as well as from the perspective of the wh-phrases themselves (i.e., movement possibilities). From the licenser point of view, we can observe the following possibilities: wh-phrase, Q-particle, defective Q, and focus. From the movement possibilities, we can see wh-in-situ with covert phrasal movement, wh-in-situ with covert feature movement, and wh-in-situ without movement. It appears to be the case that licensers do play a role, but the properties of the wh-phrases also play a role. The availability of certain licensers determines whether or not a language has extra types of wh-in-situ (aside from wh-in-situ in multiple questions). For instance, French has a defective Q-morpheme, which allows French to have matrix wh-in-situ (Cheng, 2003, p. 134). Cheng and Rooryck (2000) argue that French wh-in-situ questions are licensed by a special intonation Q-morpheme, which also licenses yes-no questions (p. 1).

A spoken language cannot be neutral and colourless. It constantly manifests our attitude to all things and all people, our acceptance or rejection of certain things, our grip or disgust. Hence a widespread use of the exclamatory interrogative sentences expressing a range of feelings up to the polar ones, for rendering of which sometimes the syntactic means themselves are not enough (Olefir, 2011, p. 252), and the interpreter practices an amplifying method of the colloquial construction by adding lexical components missing in the original:

- Comment Franck a pu aimer un navet pareil? [How Franck could like such bad movie?] (Guenassia, 2009, p. 61);

- Як Франкові взагалі може подобатися такий непотріб? [How Franck can like such junk in general?] (Guenassia, 2017, p. 69).

The parametric landscape of the wh-question formation is well known, but the motivation for why whquestions terms are displaced in some languages or stay in situ in others still remains a puzzle (Déprez, 2013, p. 4). Adli (2006) insists the wh-in-situ construction is an exclusively colloquial phenomenon, arguing the interview form allows the establishment of a close relation between the method of survey and the characteristics of the research object. Then Adli (2006) adds since the wh-in-situ construction is marked [low] on the diaphasic dimension, for some persons it is also marked [low] on the diastratic dimension, judgments are sensitive to distortions due to social desirability (p. 173). In translating of the wh-in-situ construction we observe stylistic losses because A. Shvedyk does not render the low expressiveness of the original manifested by the interrogative word removing to the end of the sentence, even emphasising it by an intensifier - the adverb me [else]: - Vouloir quoi, grand? [To want what, big?] (Guenassia, 2009, p. 75) Чого ще прагнути, мій милий? [What else to strive, my dear?] (Guenassia, 2017, p. 85). However, she could preserve the low register markedness of this sentence as we propose: - Прагнути чого, мій милий? [To want what, my dear?].

The French colloquial wh-phrases in situ in single wh-questions always appear to denote functions ranging over higher order entities, even when the wh-phrase is in the object position. As it is well-known, French has the possibility of fronting a wh-phrase or of leaving it in situ in the matrix clauses (Mathieu, 1999, p. 441). Single wh-in-situ questions in Colloquial French are not only used as standard questions asking for new information, but also as the questions with the exclamation means and colloquial words. The translator uses lexical and syntactic transformations to adequately render the original lowness of lexical and syntactic components of the exclamative interrogative sentence:

- Qu'est-ce ça peut te foutre ce qu'il y a derrière cette porte? [Why does that matter to you what's behind this door?] (Guenassia, 2009, p. 61);

- Якого дідька тобі треба знати, що за тими дверима? [What the hell do you need to know what's behind those doors?] (Guenassia, 2017, p. 69).

In spontaneous speech, the suffixation of the subject proform is insignificant and seems to be essentially confined to routine questions. According to A. Dagnac, she is nevertheless competing with the questions without extracting the word qu- (Quelle heure est-il? / Il est quelle heure? [What time is it? / It is what time?]) (Dagnac, 2013):

- Quelle heure il est, p'tit frère? [What time it is, little brother?] (Guenassia, 2009, p. 87);

- Котра година, братику? [What time, little brother?] (Guenassia, 2017, p. 97).

The structures est-ce quel c'est quel que and their variants are largely dominant (Dagnac, 2013), even the questions without the extraction of the word $q u$ - and the questions with the extraction of the word $q u$ - and assertive order. The est-ce que particle is one of the major types of interrogative formation in French, both for yes/no-interrogatives and wh-interrogatives. If it referred to as (Q) SV, it is not marked by any change in the basic word order. As a yes/no-question, it is marked by the rising intonation. As a wh-question, it has a wh-word that can be either fronted or in-situ (Waltereit, 2018, p. 61). For example, Pierre uses this colloquial interrogative construction asking Michel who does not know what he wants: 
- Au fait, est-ce que t'aimes la science-fiction, p'tit con? [By the way, do you like science fiction, little idiot?] (Guenassia, 2009, p. 50);

- До речі, любиш наукову фантастику, дурнику? [Ву the way, [you] like science fiction, dummy?] (Guenassia, 2017, p. 56).

French is the language with the relatively pronounced differences between the spoken and the written variety and between numerous speech registers. This aspect also has consequences for the methodology of the survey. Wh-in-situ questions in French are restricted to colloquial language. They have a lower value on the diaphasic dimension than the wh-variants with overt wh-movement (Adli, 2006, p. 170):

- Et toi, tu vas mettre quoi? [And you, you are going to put on what?] (Guenassia, 2009, p. 106);

- Hy а ти в чому nidem? [Well, and you, what you are going to put on?] (Guenassia, 2017, p. 117).

A variationist perspective points out an important characteristic of wh-in-situ questions in French: this construction is marked [low] on the diaphasic dimension. Wh-in-situ is a phenomenon restricted to the colloquial français familier (or to a lower register like français populaire) and is therefore also precluded from the written language. Observing the complexity of the grammatical phenomenon of French wh-in-situ, interacting with several pragmatic parameters, A. Adli opts for an empirical strategy based on the methodological triangulation (Adli, 2006, p. 170). As we can see sometimes rendering of wh-in-situ questions is non-successful:

- D'où tu viens? Tu débarques de la planète Mars ou quoi? Qui on est, d'après toi? Des communistes pourchassés? Des ennemis du peuple? Dans ce club, on est tous juifs! [Where you are from? You have come from Mars or what? Who they are, you think? Communists hunted down? Enemies of the people? In this club, they are all Jews!] (Guenassia, 2009, p. 547);

- Ти звідки взявся? 3 Марса звалився чи як? Думаєш, хто ми? Комуністи-втікачі? Вороги народу? У иъьму Клубі всі євреї! [Yои have where come from? From Mars, [you] have dropped in or how? You think, who we are? Fugitive communists? Enemies of the people? In this Club all [are] Jews!] (Guenassia, 2017, p. 572).

\section{Conclusions}

The translation analysis of the colloquial interrogatives functioning in J.-M. Guenassia's novel "The Incorrigible Optimists Club" allows us to conclude that translation difficulties are caused not so much by their textual functional features such as structural, semantic, figurative, and socio-functional characteristics, but rather by the asymmetry of the structural elements and register polyphony of the source and target languages.

The special role of colloquial interrogatives in the deployment of the communication process (to prompt the interlocutor to give information, to stimulate the deployment of the context, to activate the speech action in the dialogue, to express the communicant's relation to the subject of the request and the interlocutor) obliges the translator to find the adequate ways of rendering it as well as expanding the meanings of modalintentional constatives, expressives, and imperatives.

The colloquial interrogatives with a charge of familiarity, vernacular and argot lexemes, pose difficulties for the translator, which are also caused by the asymmetry of the register filling of the French and Ukrainian languages. In case the translator renders interrogative sentences having colloquial familiar components by neutral means, it leads to stylistic changes in the text and reduces the adequacy of the translation. Thus, the translation studies of specific functional elements of French colloquial syntax remains a topical issue.

\section{References:}

Adli, A. (2006). French wh-in-situ Questions and Syntactic Optionality: Evidence from Three Data Types. Zeitschrift für Sprachwissenschaft, 25(2), 163-203. https://doi.org/10.1515/ZFS.2006.007

Adli, A. (2013). Syntactic variation in French Wh-questions: A quantitative study from the angle of Bourdieu's sociocultural theory. Linguistics, 51(3), 473-515. https://doi.org/10.1515/ling-2013-0018

Almanova, O. (2011). Funktsionalni ta komunikatyvno-prahmatychni osoblyvosti vyslovlyuvannya-interohatyva yak zaholovka masmediynoho tekstu [Functonal and Commicative-pragmatic peculiarities of interrogative utterance as a headline of a massmedia text]. Filologichni nauky. Zbirnyk naukovyh pracz, 1(7), 99-105. Retrieved from http://pnpu.edu.ua/ua/filolohichninauky.php

Andrus, L.A. (2007). Linhvoprahmatychni kharakterystyky pytal'nykh rechen u suchasniy frantsuzkiy movi [Linguistic and pragmatic characteristics of interrogative sentences in modern French]. Doctoral thesis, Kyiv, Ukraine: Taras Shevchenko National University.

Barra-Jover, M., (2004). Interrogatives, négatives et évolution des traits formels du verbe en français parlé [Interrogatives, negatives and evolution of the formal features of the verb in spoken French]. Langue française, 1 (141), 110-125. https://doi.org/10.3917/lf.141.0110

Cheng, L. L.-S. (2003). Wh-in-situ. Part II. Glot International, 7(5), 129-137. 
Cheng, L. L.-S., \& Bayer, J. (2017). Wh-in-Situ. In M. Everaert, H. van Riemsdijk, R. Goedemans \& B. Hollebrandse (Eds.), The Blackwell Companion to Syntax (pp. 1-44). Blackwell Publishing. https://doi.org/10.1002/9781118358733.wbsyncom106

Cheng, L. L.-S., \& Rooryck, J. (2000). Licensing Wh-in-situ. Syntax, 3, 1-19. https://doi.org/10.1111/1467-9612.00022

Dagnac, A. (2014). La variation des interrogatives en français [Variation of interrogatives in French]. Retrieved July 4, 2018 from https://hal-univ-tlse2.archives-ouvertes.fr/hal-00988751

Déprez, V., \& Syrett, K., Kawahara, S. (2013). The interaction of syntax, prosody, and discourse in licensing French wh-in-situ questions, Lingua, 124, 4-19. https://doi.org/10.1016/j.lingua.2012.03.002

Gazdik, A. (2007). French Interrogatives in an OT-LFG Analysis. In M.Butt \& Holloway T.King (Eds.), Proceedings of the LFG08 Conference (pp.272-290). Stanford: CSLI Publications. Retrieved from http://csli-publications.stanford.edu/

Guenassia, J.-M. (2009). Le Club des incorrigibles optimistes [The Incorrigible Optimists Club]. Paris: Editions Albin Michel.

Guenassia, J.-M. (2017). Klub nevypravnykh optymistiv [The Incorrigible Optimists Club]. Kharkiv, Ukraine: Vivat.

Lefeuvre, F. \& Rossi-Gensane, N. (2017). Les interrogatives indirectes en discours informel oral [Indirect interrogative clauses in informal spoken French]. Langue française, 196, (4), 51-74. https://doi.org/10.3917/lf.196.0051

Mathieu, E. (1999). WH in situ and the intervention effect. In C.Iten et al. (Eds.), UCL Working Papers in Linguistics (pp. 441-472). London: University College.

Mathieu, E. (2004). The mapping of form and interpretation: the case of optional wh-movement in French. Lingua, 114, 1090-1132. https://doi.org/10.1016/j.lingua.2003.07.002

Olefir, G. I., Tabachek I.V. (2011). Pereklad rozmovnyh konstrukcij u franczuzkij hudozhnij prozi ostannogo desyatylittya (na pry kladi romanu Frederika Beigbeder "14.99 €”) [Translation of colloquial constructions in the French prose of the last decade (on the example of Frédéric Beigbeder's novel "14.99 €”]. Problemy semantyky slova, rechennya ta tekstu: Zbirnyk naukovyx pracz, 26, 248-266. Retrieved from http://philology.knu.ua/node/319

Orlov, V. V. (2001). Syntaksychni transformaciyi pry perekladi hudozhnogo tekstu [Syntactic transformations in the translation of artistic text]. In O.I. Cherednichenko (Ed.), Movni i konceptualni kartyny svitu: Zbirka naukovyh pracz / Movy, kultury ta pereklad u konteksti yevropejskogo spivrobitnycztva (pp.330-334). Kyiv, Ukraine: Tempus/Tasis, Project CP-20025-98.

Orlova, N.N. (2009). Yazykovyye sredstva vyrazheniya emotsiy: sintaksicheskiy aspekt (na materiale sovremennoy angliyskoy prozy) [Language means of expressing emotions: the syntactic aspect (based on the modern English prose)]. Doctoral thesis, Rostov na Donu, Russia.

Ponomariv, O.D. (Ed.) (2005). Suchasna ukrayinska mova [Modern Ukrainian language]. Kyiv, Ukraine: Lybid.

Shabat, S.T. (2001). Rechennya pytalnoyi modalnosti v suchasnij ukrayinskij movi [The sentences of interrogative modality in the modern Ukrainian language]. Movoznavstvo, 1, 53-58.

Shlonsky, Ur. (2012). Notes on wh in situ in French. In: L. Brugé, A. Cardinaletti, G. Giusti, N. Munaro, \& C. Poletto, Functional Heads (pp. 242-252). Oxford: Oxford University Press. https://doi.org/10.1093/acprof:oso/9780199746736.003.0019

Siemund, P. (2001). Interrogative Constructions. In M. Haspelmath, \& E. König, W. Oesterreicher, W. Raible (Eds.), Language Typology and Language Universals (pp.1010-1028). Berlin: Mouton de Gruyter,. https://doi.org/10.1515/9783110171549.2

Sitko, A.V., \& Zhuravlova, O.M. (2007) Interpretaciya anglijskyh interogatyviv pid chas perekladu ukrayinskoyu movoyu [Interpretation of English interogatives in translation into Ukrainian]. Visnyk Sumskogo derzhavnogo universytetu. Seriya Filologiya, 1 (2), 155-159. Retrieved from http://tractatus.sumdu.edu.ua/ru/2-2007/

Susov, Y. P. (2009). Lingvistycheskaya pragmatyka [Linguistic Pragmatics]. Vinnytsa, Ukraine: Nova Knyha.

Vynantova, Y.V. (2011). Yssledovanye kommunykatyvno-pragmatycheskyx osobennostej ynterrogatyvnbux kosvennblx rechevblx aktov: na materyale anglyjskyx y russkyx xudozhestvennbix tekstov [Study of communicative-pragmatic features of interrogative indirect speech acts: on the material of English and Russian fiction texts]. Doctoral thesis, Chelyabynsk, Russia.

Waltereit, R. (2018). Inferencing, Reanalysis, and the History of the French est-ce que Question. Open Linguistics, 4(1), 56-69. https//:doi:10.1515/opli-2018-0004 